PHILIPPI, Patrícia Pasqualini. Justiça restaurativa na contemporaniedade e no porvir: o diálogo democrático, sensível e humano com o direito. Revista Eletrônica Direito e Política, Programa de Pós-Graduação Stricto Sensu em Ciência Jurídica da UNIVALI, Itajaí, v.11, n.3, 30 quadrimestre de 2016. Disponível em: www.univali.br/direitoepolitica - ISSN 1980-7791

\title{
JUSTIÇA RESTAURATIVA NA CONTEMPORANIEDADE E NO PORVIR: O diÁlogo deMOCRÁTICO, SENSÍVEL E HUMANO COM O DIREITO
}

\author{
JUSTICIA RESTAURATIVA EN CONTEMPORÁNEO Y FUTURO: EL DIÁLOGO \\ DEMOCRÁTICO, SENSIBLE Y HUMANO CON LO DERECHO
}

Patrícia Pasqualini Philippi ${ }^{1}$

Pedro Manoel Abreu²

SUMÁRIO: Introdução; 1 . Um novo olhar para o direito; 2 . Justiça restaurativa; 3. Contemporaniedade e o porvir: os conflitos sociais no âmbito do sistema penal e a superação do modelo de justiça retributiva; Considerações finais; Referências bibliográficas.

\section{RESUMO}

O objeto dessa pesquisa e que se revelou e materializou no artigo que segue, volta-se a um novo ideal de justiça, e consequentemente, do Direito. Um direito que por meio da Justiça Restaurativa e suas redes, propõe a solução dos conflitos de forma democrática, sensível e reparadora. No caminho aberto pela Justiça Restaurativa o diálogo e o consenso dão o tom da reparação do mal sofrido pela vítima, substituindo-se o atual Sistema Penal, fulcrado no Direito penal retributivo, pernicioso e penalizador, por uma Justiça Restaurativa moldada nos laços do que se espera de uma Sociedade civilizada e humana. A pretensão do presente artigo é explorar essa possibilidade e dar de um novo viés para o Direito, sobretudo, no âmbito do Sistema Penal, à base de uma Justiça de entendimento e aproximação entre vítima e acusado. Logo, não se esgota aqui o assunto. Muito pelo contrário. Apenas se propõe um novo e diferente olhar para o Direito e a solução dos conflitos penais. Para a composição deste artigo, foi

\footnotetext{
${ }^{1}$ Advogada; Professora de Direito Penal, Direito Processual Penal e Introdução ao Estudo do Direito da UNIDAVI - Centro Universitário para o Desenvolvimento do Alto Vale do Itajaí; Mestre e Doutoranda em Ciência Jurídica pela Universidade do Vale do Itajaí - UNIVALI. E-mail: philippi@univali.edu.br

2 Desembargador do Tribunal de Justiça de Santa Catarina. Mestre e Doutor em Direito pela Universidade Federal de Santa Catarina. Pós-doutor pela da Faculdade de Direito da Universidade de Lisboa. Professor do Curso de Mestrado e Doutorado do Programa de Pós-Graduação em Ciências Jurídicas da Univali - Universidade do Vale do Itajaí. E-mail: pedromanoel.abreu@gmail.com
} 
PHILIPPI, Patrícia Pasqualini. Justiça restaurativa na contemporaniedade e no porvir: o diálogo democrático, sensível e humano com o direito. Revista Eletrônica Direito e Política, Programa de Pós-Graduação Stricto Sensu em Ciência Jurídica da UNIVALI, Itajaí, v.11, n.3, 30 quadrimestre de 2016. Disponível em: www.univali.br/direitoepolitica - ISSN 1980-7791

utilizado o Método Indutivo tanto na fase de investigação quanto na apresentação do relato dos seus resultados e, conjuntamente, foram adotadas as Técnicas do Referente, da Categoria, do Conceito Operacional e da Pesquisa Bibliográfica.

Palavras-Chave: Diálogo. Democrático. Sensível. Humano. Direito. Justiça Restaurativa. Sistema Penal.

\section{RESUMEN}

El objeto de esta investigación y se revelaron y se dieron cuenta en el siguiente artículo, de nuevo a un nuevo ideal de la justicia, y por lo tanto la ley. Una derecha a través de la justicia restaurativa y sus redes, propone la solución de los conflictos de una manera democrática, sensible y reparadora. En el camino abierto el diálogo y el consenso Justicia Restaurativa dan tono de la reparación sufrido por la víctima, en sustitución del actual sistema penal, fulcrado en lo Derecho Penal Retributivo, traviesa y punitivo, por una forma de justicia restaurativa en los lazos que esperar de una sociedad civilizada y humana. La intención de este artículo es explorar esta posibilidad y dar un nuevo giro a la ley, especialmente en el marco del sistema penal, la base de un juez de la comprensión y el acercamiento entre la víctima y el acusado. Por lo tanto, no termina el asunto aquí. Al contrário. Sólo propone una mirada nueva y diferente a la ley y la resolución de los conflictos penales. Para la composición de este artículo, se utilizó el método inductivo, tanto en la fase de investigación y en la presentación del informe de los resultados $y$, en conjunto, las técnicas fueron adoptados de referente, Categoría, el concepto operacional de Investigación y Biblioteca.

PALABRAS ClAVE: Diálogo. Democrático. Sensible. Humana. Derecho. Justicia Restaurativa. Sistema Penal.

\section{INTRODUÇÃO}

O presente artigo tem por objetivo a análise da Justiça Restaurativa, na contemporaniedade e no porvir, como um novo modelo de solução de conflitos alternativo ao aplicado pelo atual Sistema Penal, calcado no exercício do entendimento e do diálogo, priorizando assim as bases da democracia e do humano.

A ideia é irromper com as práticas repressivas e punitivas, buscando-se na interação e na superação da crise que se estabece entre a vítima e o autor de um crime, uma verdadeira solução para o conflito, com a mínima ou nenhuma interferência do Estado. 
PHILIPPI, Patrícia Pasqualini. Justiça restaurativa na contemporaniedade e no porvir: o diálogo democrático, sensível e humano com o direito. Revista Eletrônica Direito e Política, Programa de Pós-Graduação Stricto Sensu em Ciência Jurídica da UNIVALI, Itajaí, v.11, n.3, $3^{\circ}$ quadrimestre de 2016. Disponível em: www.univali.br/direitoepolitica - ISSN 1980-7791

No primeiro item convida-se o leitor a um novo olhar para o Direito, explorandose os riscos que a contemporaniedade e o próprio futuro estão a indicar, a multiplicação e a instalação de novos riscos e conflitos, o que jusifica, por conseguinte, uma nova forma de ver, compreender e aplicar o Direito na resolução dessas celeumas.

O segundo item dedica-se por sua vez a estudar a Justiça Restaurativa como um modelo novo de solução de conflitos, detidamente neste artigo voltada a análise no âmbito penal, baseado na Democracia, na desjudicialização, no diálogo e na aproximação das pessoas (vítima e acusado).

No terceiro e último item, analisa-se a Justiça Restaurativa como uma das alternativas à superação do Sistema Penal, identificando na primeira um fenômeno que se desencadeia numa perspectiva menos seletiva, perniciosa e cruel daquela que o Estado tem, de regra, a oferecer.

Dentro ou fora do Sistema Penal, é um modelo que precisa ser investigado e experimentado para que na e com a sua praxis, se possa efetivamente estabelecer seu alcance como instrumento no combate da criminalidade, na cura das feridas causadas pelo crime, e, sobretudo, na restauração dos danos causados pelo conflito e sua efetiva solução.

$\mathrm{Na}$ elaboração do artigo foi utilizado o Método Indutivo, tanto na Fase de Investigação quanto na apresentação do relato dos seus resultados e, conjuntamente, foram adotadas as Técnicas do Referente ${ }^{3}$, da Categoria ${ }^{4}$, do Conceito Operacional ${ }^{5}$ e da Pesquisa Bibliográfica ${ }^{6}$.

\footnotetext{
${ }^{3}$ Conceitua-se Referente como "a explicitação prévia do(s) motivos, do(s) objetivo(s) e do produto desejado, delimitando o alcance temático e de abordagem para uma atividade intelectual, especialmente para uma pesquisa." (PASOLD, Cesar Luiz. Metodologia da Pesquisa Jurídica: teoria e prática. 12. ed. rev. São Paulo: Conceito Editorial, 2011, p. 54)

${ }^{4}$ Denomina-se Categoria "a palavra ou expressão estratégica à elaboração e/ou à expressão de uma ideia." (PASOLD, Cesar Luiz. Metodologia da Pesquisa Jurídica: teoria e prática. 12. ed. rev. São Paulo: Conceito Editorial, 2011, p. 25)

${ }^{5}$ Conceito Operacional é a "definição para uma palavra ou expressão, com o desejo de que tal definição seja aceita para os efeitos das ideias que expomos". (PASOLD, Cesar Luiz.
} 
PHILIPPI, Patrícia Pasqualini. Justiça restaurativa na contemporaniedade e no porvir: o diálogo democrático, sensível e humano com o direito. Revista Eletrônica Direito e Política, Programa de Pós-Graduação Stricto Sensu em Ciência Jurídica da UNIVALI, Itajaí, v.11, n.3, 30 quadrimestre de 2016. Disponível em: www.univali.br/direitoepolitica - ISSN 1980-7791

\section{UM NOVO OLHAR PARA O DIREITO}

A história nos conta e mostra que o direito é um importante instrumento de limitação de poder do Estado e também um poderoso mecanismo que regula a transformação da Sociedade ${ }^{7}$ e da sua ordem política, econômica, social e cultural.

A partir do século XIX, com a Revolução Industrial e a contar daí a ideia de Modernidade, os compentes do Estado, Sociedade e por consequência do próprio Direito, sofreram profundas alterações. E como esses não são elementos estanques, seus redesenhos continuam em constante mutação.

Com a modernidade ou com seu caminhar para o Estado Contemporâneo, viuse estabelecer a transposição das fronteiras, a globalização ${ }^{8}$, o encurtamento das

Metodologia da Pesquisa Jurídica: teoria e prática. 12. ed. rev. São Paulo: Conceito Editorial, 2011, p. 37)

${ }^{6}$ Pesquisa Bibliográfica é expressão que indica a "Técnica de investigação em livros, repertórios jurisprudenciais e coletâneas legais." (PASOLD, Cesar Luiz. Metodologia da Pesquisa Jurídica: teoria e prática. 12. ed. rev. São Paulo: Conceito Editorial, 2011, p. 209)

7 A opção da autora da presente Dissertação para este tipo de grafia se sustenta no seguinte argumento: "[...] se a Categoria ESTADO merece ser grafada com a letra E maiúscula, muito mais merece a Categoria SOCIEDADE ser grafada com a letra $\mathrm{S}$ em maiúscula, porque, afinal, a SOCIEDADE é a criadora e mantenedora do Estado! Por coerência, pois, se a criatura/mantida (Estado) vem grafada com E maiúsculo, também e principalmente a criadora/mantenedora (Sociedade) deve ser grafada com o S maiúsculo!". Conforme PASOLD, Cesar Luiz. Metodologia da Pesquisa Jurídica: teoria e prática. 12. ed. rev. São Paulo: Conceito Editorial, 2011, p. 169. (negritos e destaques no original)

8 Globalização, por Luiz Fernando Coelho, trata-se de "[...] um poderoso processo de estandardização da cultura a nível mundial. Só que isso ocorre segundo os padrões e critérios de quem detém a maior parcela de poder na sociedade pelo domínio da informação, da ciência e da tecnologia; e um tal poder hoje transcende a nação e o Estado, projetando-se como poder mundial, não somente militar e econômico, mas científico, cultural e ideológico.[...] $\mathrm{E}$ o resultado desse processo, o fruto mais evidente e provavelmente mais nefasto da globalização e, como igualmente jamais se anteviu, a unidimensionalização do ser humano, traduzida na conformização com padrões heterônomos que tratam de amoldar não somente seu comportamento exterior, como também sua alma interior, sua cultura e seu sentimento."In: COELHO, Luiz Fernando. Saudade do Futuro: transmodernidade, direito, utopia. Florianópolis: Fundação Boiteux, 2001, p. 20 
PHILIPPI, Patrícia Pasqualini. Justiça restaurativa na contemporaniedade e no porvir: o diálogo democrático, sensível e humano com o direito. Revista Eletrônica Direito e Política, Programa de Pós-Graduação Stricto Sensu em Ciência Jurídica da UNIVALI, Itajaí, v.11, n.3, $3^{\circ}$ quadrimestre de 2016. Disponível em: www.univali.br/direitoepolitica - ISSN 1980-7791

distâncias, o tráfego de meios dinâmicos de produção e a conversão dos mecanismos políticos em econômicos. ${ }^{9}$

Neste compasso, os modelos de Estado, nas suas acepções políticas e socais, também foram reformulados. De um Estado Absoluto - anterior a Revolução Francesa - partiu-se por influência dessa, para um Estado de Direito; já na metade do Século XX, para um Estado Social, e, por fim, para um Estado Contemporênao, que na maioria dos países se mostram na forma de Estados Democráticos de Direito.

Sob este prisma, vale lembrar que da relação antagônica entre Estado e Sociedade Civil, partiu-se à compreensão de que esta é um fator preponderante de transformação da estrutura material daquele ${ }^{10}$. Logo, há assim, uma estreita ligação entre o modelo de Estado e o Direito, podendo-se observar que na medida em que exista uma mudança do primeiro, existirá também uma alteração do Direito e nesta toada, de proteção dos direitos fundamentais dos indivíduos ${ }^{11}$.

Esses e muitos outros fenômenos, que no estágio do Estado Contemporâneo "transpasse da modernidade, para alguns definido como pós modernidade e para outros ainda, transmodernidade"12 - somam-se à transnacionalidade, a facilidade e rapidez da comunicação, a liberdade de informação, a mobilidade humana, o multiculturalismo redundaram em novos paradigmas ${ }^{13}$ do Direito, em

9 GUIMARÃES. Isaac Sabbá. Globalização, Transnacionalidade e os Contornos de uma Democracia da Pós-Modernidade. In PASOLD, Cesar; SANTO, Davi do Espírito. Reflexões sobre a Teria da Constituição e do Estado. Florianópolis: Insular, 2013, p. 325

10 Ver BRANDÃO, Paulo de Tarso. As Ações Constitucionais: novos direitos e acesso à justiça. Florianópolis: Habitus, 2001, p. 51-52

11 STRECK, Maria Luiza Schafer. Direito penal e Constituição: a face oculta da proteção dos direitos fundamentais. Porto Alegre: Livraria do Advogado Editora, 2009, p. 59

12 ABReU, Pedro Manuel. Processo e Democracia: o processo jurisdicional como um locus da democracia participativa e da cidadania inclusiva no estado democrático de direito. v.3. São Paulo: Conceito Editorial, 2011, p. 131

13 Segundo Paulo Márcio Cruz e Zenildo Bodnar," Especificamente no campo da ciência jurídica, com o direito como seu objeto, por paradgima deve-se entender o critério de racionalidade epistemológica reflexiva que predomina, informa, orienta e direciona a resolução dos problemas, desafios, conflitos e o próprio funcionamento da sociedade. Trtata-se de um referente a ser seguido e que ilumina a produção e aplicação do direito." In: CRUZ, Paulo Márcio; BODNAR, 
PHILIPPI, Patrícia Pasqualini. Justiça restaurativa na contemporaniedade e no porvir: o diálogo democrático, sensível e humano com o direito. Revista Eletrônica Direito e Política, Programa de Pós-Graduação Stricto Sensu em Ciência Jurídica da UNIVALI, Itajaí, v.11, n.3, $3^{\circ}$ quadrimestre de 2016. Disponível em: www.univali.br/direitoepolitica - ISSN 1980-7791

novas áreas de conflitos e impõe, nesta mesma ordem, uma outra e renovada forma de apreciá-los, concebê-los e resolvê-los.

Para Cruz, na esfera mundial já se consolidaram novos poderes vinculados à globalização, o que impõe um refundar das bases que sustentam a política mundial, de modo mais universal e menos excludente, ou seja, para o autor, é preciso construir uma 'globalização republicana'14.

Na virada para o Estado Contemporâneo - Democrático e de Direito ${ }^{15}$ e no se que espera Republicano ${ }^{16}$, e também no que está porvir, toda a base do Direito deve perpassar pelas normas de uma Constituição, que é a identidade política e social de um dado país bem como, a forma com que este regulará e atenderá seus indivíduos.

A Constituição confere uma unidade de sentido, valor e concordância prática aos direitos fundamentais, repousando na dignidade humana, que faz da pessoa fundamento e fim da Sociedade e do Estado. ${ }^{17} \mathrm{E}$ nessa escala, tais direitos são absolutos, ao tempo que se apresenta e quando limitados, só o serão "somente pela Constituição mesma"18.

Zenildo. $\quad 0$ Novo Paradigma de Direito na Pós-Modernidade. Porto Alegre. RECHTD/UNISINOS. RECHTD. Revista de Estudos Constitucionais, Hermenêutica e Teoria do Direito, v. 3, p. 2011 , p. 78

${ }^{14}$ CRUZ, Paulo Márcio. Da soberania à transnacionalidade: democracia, direito e estado no século XXI. Itajaí: Universidade do Vale do Itajaí, 2011, p. 50

15 "[...] entendido como aquele que intervém nos domínios econômico, social e cultural, obedecidos os parâmetros mínimos de cidadania, política, justiça, representatividade, legalidade e legitimidade". CRUZ, Paulo Márcio. Política, Poder, Ideologia \& Estado Contemporâneo. Curitiba: Juruá, 2002, p.125

16 Para Paulo Márcio Cruz e Sérgio Antônio Scmitz, "A República é a forma de governo na qual a Democracia se funde ao Estado de Direito. [...] E quando, maior for o controle popular, quanto mais capazes de distinguir o bem comum dos interesses privados, mais republicanas serão estas pessoas e mais democrático será o poder. In: CRUZ, Paulo Marcio; SCHMITZ, Sérgio Antônio. Sobre o Princípio Republicano. NEJ.- Vol. 13 - 1- p. 43-54/jan-jun 2008, p. 47

${ }^{17}$ MIRANDA, Jorge. Manual de Direito Constitucional. v.4. Coimbra: Coimbra, 1988, p. 166

${ }^{18}$ HESSE, Konrad. Elementos do Direito Constitucional da República Federal da Alemanha. Tradução Luís Afonso Heck. Porto Alegre: Sérgio Antônio Fabris, 1995, p. 254 
PHILIPPI, Patrícia Pasqualini. Justiça restaurativa na contemporaniedade e no porvir: o diálogo democrático, sensível e humano com o direito. Revista Eletrônica Direito e Política, Programa de Pós-Graduação Stricto Sensu em Ciência Jurídica da UNIVALI, Itajaí, v.11, n.3, $3^{\circ}$ quadrimestre de 2016. Disponível em: www.univali.br/direitoepolitica - ISSN 1980-7791

Nas palavras de Cruz:

A Constituição Democrática aparece, então, como instrumento para tornar compatível o império da vontade popular e as garantias do Estado de Direito. A definição dos direitos fundamentais e garantias constitucionais, a organização dos poderes e a previsão dos procedimentos que atuam legitimamente estabelecem os parâmetros para a manifestação da vontade popular. [...] O Estado Democrático de Direito passou a ser, portanto, uma proposta de civilização, muito mais do que uma questão ideológica ou jurídica, ressalte-se mais uma vez ${ }^{19}$.

Propositamente, fala-se aqui em ser humano, pois na contemporaniedade, até mesmo o conceito de cidadão emerge em crise. Isto porque a definição de cidadania não é algo estagnado, é um conceito histório, cujo sentido varia no tempo e no espaço, sob as perspectivas da titularidade e conteúdo.

O conceito de cidadania, tem portanto, ao longo do tempo, alterado-se em cada um dos espaços territorias, sociais e políticos, seja para incorporar ou não os imigrantes, no que se refere ao grau de participação dos diferentes grupos, bem como, no tocante à proteção fornecida pelo Estado, aos que dela necessitam. ${ }^{20}$

Essa proteção implica umbilicalmente a promoção, consolidação, eficácia e garantia de direitos fundamentais, entendidos por aqueles que equivalem a um conjunto de normas de um ordenamento jurídico positivo, calcado na moralidade, na proteção da dignidade humana e nos valores de liberdade e igualdade e que correspondem as normas materiais básicas desse

${ }^{19}$ CRUZ, Paulo Márcio. Fundamentos do Direito Constitucional. 2 ed. Curitiba: Juruá, 1998, p. 215

20 CADERMATORI. Daniela Mesquita Leutchuk de. Limites e Possibilidades de uma Cidadania Transnacional: uma apreensão histórico-cultural. In: CRUZ, Paulo Márcio; STELZER, Joana (Orgs.) Direito e Transnacionalidade. Curitiba: Juruá, 2011, p. 140 
PHILIPPI, Patrícia Pasqualini. Justiça restaurativa na contemporaniedade e no porvir: o diálogo democrático, sensível e humano com o direito. Revista Eletrônica Direito e Política, Programa de Pós-Graduação Stricto Sensu em Ciência Jurídica da UNIVALI, Itajaí, v.11, n.3, $3^{\circ}$ quadrimestre de 2016. Disponível em: www.univali.br/direitoepolitica - ISSN 1980-7791

ordenamento $^{21}$. São direitos e liberdades previstos e protegidos pela própria Constituição ${ }^{22}$.

Como esclarece Alexy "a exigência de se levar a sério as determinações estabelecidas pelas disposições de direitos fundamentais, isto é, de levar a sério o texto constitucional, é um parte do postulado de vinculação à Constituição"23.

No entanto, alerta Canotilho, "não basta a consagração de direitos numa qualquer Constituição"24. É preciso que a constitucionalização dos direitos revele a fundamentabilidade dos direitos e reafirme apositividade no sentido de os direitos serem posições juridicamente garantidas e não apenas proclamações filosóficas, pois devem legitimar a própria ordem constitucional como ordem de liberdade e de justiça ${ }^{25}$.

Do mesmo modo, a democracia, por si só, não é senhora do ideal de Direito e nem tampouco, da Justiça Social. Escreve Abreu, citando Dahl, "que a democracia não pode assegurar que todos os cidadãos sejam felizes, prósperos, saudáveis, sábios, pacíficos ou justos $[\ldots]^{\prime 26}$. E adverte, que apesar das falhas, não se pode deixar de pensar nos benefícios que tornam a democracia a mais desejável das alternativas ${ }^{27}$.

21 MARTINEZ, Gregório Perces-Barba. Derecho y derecho fundamentales. Madri: Centro de Estudios Constitucionales, 1993, p. 323

22 CRUZ, Paulo Márcio. Fundamentos do Direito Constitucional. 2 ed. Curitiba: Juruá, 1998, p.153

23 ALEXY, Robert. Teoria dos Direitos Fundamentais. Tradução de Virgílio Afonso da Silva. São Paulo: Malheiros Editores, 2008, p. 140

${ }^{24}$ CANOTILHO, José Joaquim Gomes. Estado de direito. Coimbra: Gradiva, 1999, p.56

${ }^{25}$ CANOTILHO, José Joaquim Gomes. Estado de direito. Coimbra: Gradiva, 1999, p.56

26 ABReU, Pedro Manuel. Processo e Democracia: o processo jurisdicional como um locus da democracia participativa e da cidadania inclusiva no estado democrático de direito. v.3. São Paulo: Conceito Editorial, 2011, p. 177

27 ABReU, Pedro Manuel. Processo e Democracia: o processo jurisdicional como um locus da democracia participativa e da cidadania inclusiva no estado democrático de direito. v.3. São Paulo: Conceito Editorial, 2011, p. 177 
PHILIPPI, Patrícia Pasqualini. Justiça restaurativa na contemporaniedade e no porvir: o diálogo democrático, sensível e humano com o direito. Revista Eletrônica Direito e Política, Programa de Pós-Graduação Stricto Sensu em Ciência Jurídica da UNIVALI, Itajaí, v.11, n.3, 30 quadrimestre de 2016. Disponível em: www.univali.br/direitoepolitica - ISSN 1980-7791

Nesse linear e diante de tantas mudanças resultado da globalização e da pósmodernidade, o porvir é um espaço a ser ocupado com as armas de um Direito vinculado à Constituição em seu sentido forte; com as garantias aos direitos fundamentais trazidas à reboque de um Estado Democrático de Direito, com fim na justiça social. Logo, é preciso superar alguns postulados modernos do direito. É preciso, portanto, parafraseando Dworkin, levar o Direito a sério ${ }^{28}$.

Para Dias, "a centralidade de um novo projeto ético-político deve residir na Pessoa"29. Para a autora, a dignidade humana e o direito à vida com qualidade constituem o projeto ideal do Estado Democrático de Direito, que deve ser funcionalizado para realizar os direitos fundamentais assegurados nas constituições, acordos e tratados internacionais, para toda a pessoa humana e de qualquer dos povos ${ }^{30}$.

Essa referência e esse apego à Constituição, visa mitigar os efeitos resultantes de uma Sociedade que é cada vez mais um profícuo organismo de riscos. Esse é um fenômeno hodierno e imprevisível que emerge da sociedade pós-moderna, pós industrial e se caracteriza fundamentalmente pela imprevisibilidade dos riscos ou então, pelo aparecimento de novos riscos ${ }^{31}$.

Ademais, como já reescreveu Guimarães e Carvalho, "a Sociedade, hoje mais do que ontem e, muito possivelmente, menos do que amanhã, é absolutamente

${ }^{28}$ Levando os Direitos à Sério. Nome que dá título à obra de Ronald Dworkin, jusfilósofo norteamericano que trata dos direitos fundamentais à luz do ordenamento jurídico americano. DWORKIN, Robert. Levando os Direitos a Sério. Tradução de Nelson Boeira. São Paulo: Martins Fontes, 2007

29 DIAS, Maria da Graça dos Santos. Direito e Pós- Modernidade. In: DIAS, Maria da Graça dos Santos; MELO, Osvaldo Ferreira de; Silva, Moacyr Motta da. Política Jurídica e PósModernidade. Florianópolis: Conceito Editorial, 2009, p.15

30 DIAS, Maria da Graça dos Santos. Direito e Pós- Modernidade. In: DIAS, Maria da Graça dos Santos; MELO, Osvaldo Ferreira de; Silva, Moacyr Motta da. Política Jurídica e PósModernidade. Florianópolis: Conceito Editorial, 2009, p.15

${ }^{31}$ FERNANDES, Paulo Silva. Globalização, "Sociedade de Risco" e o Futuro do Direito Penal. Coimbra: Livraria Almedina, 2001, p. 10 
PHILIPPI, Patrícia Pasqualini. Justiça restaurativa na contemporaniedade e no porvir: o diálogo democrático, sensível e humano com o direito. Revista Eletrônica Direito e Política, Programa de Pós-Graduação Stricto Sensu em Ciência Jurídica da UNIVALI, Itajaí, v.11, n.3, $3^{\circ}$ quadrimestre de 2016. Disponível em: www.univali.br/direitoepolitica - ISSN 1980-7791

conflituosa, longe, portanto, de se configurar como harmônica e em que predomine a paz social" ${ }^{\prime 32}$.

Nunca, portanto, estivemos tão distantes do ideal de Arcádia $^{33}$, local onde reinariam a paz, a felicidade e a segurança. Um jardim preservado de todo o perigo. A residência dos homens de bem, um sonho que habitou entre o mito e a verdade, durante milênios, o espírito andante dos mais utopista dos homens. ${ }^{34}$

Para o resgate ou talvez, com mais lógica, para o estabelecimento de um Estado e de uma Sociedade mais humana, e por conseguinte, para que se possa também pensar na implementação de uma nova ordem jurídica, mitigadora dos aparatos de castração que o Estado tende a manter para resolução dos conflitos e contenção das classes e indivíduos, quem sabe a fraternidade seja um fundamento e uma hipótese a se melhor pensar. Nesta esteira,

[...] a fraternidade é que dará condição para repensar a Sociedade. Sociedade pautada nas relações concretas qualquer que sejam suas formas e tipos; reais, potenciais ou virtuais - entre as pessoas humanas que, desenvolvidas culturalmente têm capacidade para agir na vida, dando sentido a existência humana, de forma conceber um espaço público mundial em busca de uma convivência pacífica, digna e sustentável para esse cenário global que se apresenta à realidade contemporânea ${ }^{35}$.

A contemporaneidade e o porvir, exigem, portanto, um olhar detalhado sobre o Estado, a Sociedade e daquilo que resulta, sobressai e exige dos e entre os dois,

32 GUIMARÃES, Cláudio Alberto Gabriel; CARVALHO, Themis Maria Pacheco de. Os descaminhos da prestação jurisdicional no âmbito punitivo. Algumas considerações sobre as reformas do código do Código de Processo Penal Brasileiro. In: SPENGLER, Fabiana Marion; BRANDÃO, Paulo de Tarso. Os (des)caminhos da jurisdição. Florianópolis: Conceito Editorial. 2009, p.102-103

33 Arcádia ou Sonho de Arcádia, é um termo criado por poetas e artistas, sobretudo, do Renascimento, para identificar o lugar que corresponde a vida na terra como um paraíso sonhado. É um lugar imaginado onde reina a felicidade, a simplicidade e a paz. Conceito da autora

34 FERnANDES, Paulo Silva. Globalização, "Sociedade de Risco" e o Futuro do Direito Penal. Coimbra: Livraria Almedina, 2001, p. 115

35 SILVA, Ildete Regina Vale da; BRANDÃO, Paulo de Tarso. Constituição e Fraternidade: o valor normativo do preâmbulo da constituição. Curitiba: Juruá, 2015, p. 109-110 
PHILIPPI, Patrícia Pasqualini. Justiça restaurativa na contemporaniedade e no porvir: o diálogo democrático, sensível e humano com o direito. Revista Eletrônica Direito e Política, Programa de Pós-Graduação Stricto Sensu em Ciência Jurídica da UNIVALI, Itajaí, v.11, n.3, 30 quadrimestre de 2016. Disponível em: www.univali.br/direitoepolitica - ISSN 1980-7791

do próprio Direito. A compreensão de que as dinâmicas sociais irrompem e impõem a rediscussão dos velhos conceitos, sobretudo quanto à ordem jurídica, que deverá se revelar em uma linguagem capaz de enfrentar ambientes assimétricos, globais e de risco de forma mais humana, dialogada, pacificadora é emergencial.

É preciso pensar no novo, pois como afirma Beck "O núcleo da consciência do risco não está no presente, e sim no futuro"36. O Direito não pode ficar estanque as mudanças e avanços sociais, políticos, econômicos ou culturais. E mais, deve e precisa dar sua virada para o que há de melhor, lembrando do passado, vivendo do presente e pensando no futuro.

O que se espera é que o Direito transpasse as barreiras de tempo, lugar e pessoas, que passe ao largo das categorias do passado, do poder excludente, castrador do Estado. Que invista e insista, numa consciência universal, democrática, reguladora e limitadora do poder, que imprima respeito à humanidade, à dignidade, à sensibilidade e, sobretudo, na construção de um novo modelo de solução dos conflitos sociais.

"Aliás, [...] a mesma materialidade, atualmente utilizada para construir um mundo confuso e perverso, pode vir a ser uma condição da construção de um mundo mais humano $[\ldots]^{\prime \prime 37}$. Ao menos, é o que se espera.

Essa perspectiva, fundada na quebra de antigos paradigmas e na necessidade de reanálise dos vínculos e dos relacionamentos políticos, econômicos, sociais e culturais, faz surgir a partir de novos espaços públicos um Estado que mira à sua Sociedade com um Direito que se pretende consolidar na esfera do fraterno, do democrático, do sensível e do humano.

Este novo ordenamento não é apenas reflexo da necessidade em se solucionar as atuais contendas políticas, econômicas, sociais e culturais, mas parece

${ }^{36}$ BECK, Ulrich. Sociedade de Risco: rumo a uma outra modernidade. 2 ed. Tradução de Sebastião Nascimento. São Paulo: Editora 34, 2011, p. 40

37 SANTOS, Milton. Por uma outra globalização: do pensamento único à consciência universal. Rio de Janeiro: Record, 2011, p. 170 
PHILIPPI, Patrícia Pasqualini. Justiça restaurativa na contemporaniedade e no porvir: o diálogo democrático, sensível e humano com o direito. Revista Eletrônica Direito e Política, Programa de Pós-Graduação Stricto Sensu em Ciência Jurídica da UNIVALI, Itajaí, v.11, n.3, 30 quadrimestre de 2016. Disponível em: www.univali.br/direitoepolitica - ISSN 1980-7791

expressar também uma vontade política mundial de soluções de conflitos, harmônica entre as nações, de respeito aos direitos fundamentais e de sobrevivência da própria humanidade.

Por essa razão e pela necessidade de se pensar em algo que diminua os conflitos e por outro lado, fortaleça a evolução e os laços de consenso que devem permear a humanidade, é preciso um novo olhar para o Direito. Um Direito que será aqui tratado não na sua estreita relação com a Dogmática Jurídica, mas, sobretudo, na concepção de que o mesmo se estabelece, para além disso, como fenômeno cultural, social e político ${ }^{38}$.

\section{JUSTIÇA RESTAURATIVA ${ }^{39}$}

As relações humanitárias devem ser matizadas por um nova ordem jurídica, fulcradas no diálogo, no consenso e no entendimento, ainda que o conflito se instale dentro de um Sistema Penal.

É preciso pensar na criação, adoção ou implementação de um arquétipo de solução de conflitos que seja mais democrático e humano e que atenda sob à luz da Constituição, a correlação entre o Direito e a Democracia.

Como um dia escreveu Dias:

O Direito, para ser efetivamente justo, democrático e ético supõe uma atitude de presença, de atenção, de cuidado com a vida (da natureza, do homem e da sociedade). Necessita compreender os desafios próprios da vida cotidiana, prescrutando o imaginário social para aí identificar as carências, sonhos, utopias, desejos, esperanças e

38 SILVA, Moacyr Motta da. Direito e Sensibiliade. In: DIAS, Maria da Graça dos Santos; MELO, Osvaldo Ferreira de; Silva, Moacyr Motta da. Política Jurídica e Pós- Modernidade. Florianópolis: Conceito Editorial, 2009, p. 218-219.

39 Texto revisado reescrito pela da própria autora. $\mathrm{Na}$ sua versão original, este texto foi desenvolvido na produção do Artigo: O Caráter Transnacional das Proposições de Justiça Restaurativa, em abril de 2016. Artigo submetido à publicação. 
PHILIPPI, Patrícia Pasqualini. Justiça restaurativa na contemporaniedade e no porvir: o diálogo democrático, sensível e humano com o direito. Revista Eletrônica Direito e Política, Programa de Pós-Graduação Stricto Sensu em Ciência Jurídica da UNIVALI, Itajaí, v.11, n.3, $3^{\circ}$ quadrimestre de 2016. Disponível em: www.univali.br/direitoepolitica - ISSN 1980-7791

desesperanças que portam as pessoas, as comunidades e a sociedade como um todo ${ }^{40}$.

A Democracia e o Direito formam uma via de mão única. E são nas relações sociais, especialmente as que se voltam ao Sistema Penal, que este trajeto, ainda que tortuoso e movimentado, deve ser percorrido, pois como disse Warat:

[...] não existe democracia sem marginalidade (adultério), sem uma louca cavalgada, o delírio febril, os ais do amor que vêm da experiência comum da gente, surgida nos momentos primordiais do cotidiano, na encruzilhada da fome e da hipocrisia (da ordem prepotente) com os elementos imaginativos mais ousados que incendeiam a liberdade em cada esquina ${ }^{41}$.

A ideia, portanto, é senão sair do Sistema Penal, ao menos reduzi-lo, partindo-se de um modelo de solução de conflitos que mitigue a invasividade $e$ ofensividade do Estado e que priviligie um Direito democrático e de entendimento.

Esse modelo, que se convecionou chamar de Justiça Restaurativa, começou a se instalar na década de 80 e primeiramente ganhou destaque junto aos movimentos abolicionistas. Jonh Braithwaite, criminólogo australiano, foi um dos primeiros entusiastas desse modelo, tendo publicado "Crime, Shame and Reitegration" ${ }^{42}$ e defendido também o amálgama republicado de justiça, ao viés da Justiça Restaurativa.

Dada, porém, a sua imagem premiada pela radicalidade, porquanto, parecia pretender substituir o modelo tradicional de justiça penal, alocando a recuperação do conflito à própria vítima, ou à esfera cível ou administrativa, muitos juristas e também a comunidade em geral, além de não acreditarem na

40 DIAS, Maria da Graça dos Santos. Direito e Pós- Modernidade. In: DIAS, Maria da Graça dos Santos; MELO, Osvaldo Ferreira de; Silva, Moacyr Motta da. Política Jurídica e PósModernidade. Florianópolis: Conceito Editorial, 2009, p.44.

${ }^{41}$ WARAT, Luís Alberto. A ciência jurídica e seus dois maridos. Santa Cruz do Sul: Faculdades Integradas de Santa Cruz do Sul, 1985, p.22

42 BRAITHWAITE, John. Crime, shame and reintegration. Cambridge: Cambridge University Press, 1989 
PHILIPPI, Patrícia Pasqualini. Justiça restaurativa na contemporaniedade e no porvir: o diálogo democrático, sensível e humano com o direito. Revista Eletrônica Direito e Política, Programa de Pós-Graduação Stricto Sensu em Ciência Jurídica da UNIVALI, Itajaí, v.11, n.3, $3^{\circ}$ quadrimestre de 2016. Disponível em: www.univali.br/direitoepolitica - ISSN 1980-7791

eficiência do método, viam no mesmo um pernicioso mecanismo de supressão do processo, e, portanto, dos direitos e garantias do acusado.

Nos anos 90, os Estados Unidos, numa alternativa que melhor dialogava com o sistema vigente desenvolveu uma ideia mais acurada de Justiça Restaurativa, paradigma este que se estendeu para vários outros países, notadamente a partir do ano 2000, com o advento da Declaração de Viena sobre a Criminalidade e Justiça.

Em 2002, o Conselho Econômico e Social das Nações Unidas adotou a Resolução 2002/12, recomendando assim aos Estados-membros a implementação da Justiça Restaurativa. Também em 2005, com a Declaração de Bangkok, mais uma vez se reiterou a importância de se desenvolver este novo formato de solução de conflitos.

Em 2006, foi ainda publicado o manual da ONU, tratando de programas de Justiça Restaurativa, dando a tônica da importância e grau de desenvolvimento do assunto e que de lá para cá só vem aumentando. A propósito, só no Brasil, várias são as leis já em vigor a tratar do assunto, ainda que de forma tímida ou parcial $^{43}$.

A Europa, por sua vez e na mesma toada, criou o Fórum Europeu de Mediação Penal e Justiça Restaurativa, e na América Latina, o modelo sendo aplicado em países a exemplo da Colômbia e o Brasil. A proposta, portanto, aponta para um aceno mundial.

Neste sentido, é importante ressaltar que esse modelo se insere nos postulados contemporâneos de um Estado Democrático de Direito. Habermas a este respeito, teoriza a ideia na sua obra Direito e Democracia ${ }^{44}$, defendendo assim

\footnotetext{
${ }^{43}$ Lei que criou os Juizados Especiais Criminais - Lei 9.099/95; Estatuto da Criança e Adolescente Lei 8.069/90; Código Penal em seus artigos 43 e 44; Lei de Mediação - Lei 13.140/2015; e determinações do próprio Conselho Nacional de Justiça. Disponível em: http://www.cnj.jus.br/noticias/cnj/81051-cnj-servico-conceitos-basicos-da-justica-restaurativa. Acesso em 03/04/2016.

${ }^{44}$ HABERMAS, Jürgen. Direito Democracia - entre facticidade e validade. Trad. Flávio Beno Siebeneichler. Rio de Janeiro: Tempo Brasileiro, v. I e II, 2003.
} 
PHILIPPI, Patrícia Pasqualini. Justiça restaurativa na contemporaniedade e no porvir: o diálogo democrático, sensível e humano com o direito. Revista Eletrônica Direito e Política, Programa de Pós-Graduação Stricto Sensu em Ciência Jurídica da UNIVALI, Itajaí, v.11, n.3, 30 quadrimestre de 2016. Disponível em: www.univali.br/direitoepolitica - ISSN 1980-7791

a concepção de uma ação comunicativa, que inspira os postulados da Justiça Restaurativa.

Para a Justiça Restaurativa, o crime passa a ser entendido "como um dano e uma violação de pessoas e relacionamentos. A justiça deveria se concentrar na reparação, em acertar o que não está certo"45. Logo, o crime passa a ensejar uma reação que se desencadeará em uma composição ou reparação da lesão, diferentemente do que ocorre dentro do sistema penal punitivo, onde o que se opera é uma mera retribuição estatal, de ordem punitiva e não reparadora, pelo mal causado.

Trata-se assim de um modelo em que a vítima e não o Estado passa a ser o verdadeiro sujeito da relação conflituosa e onde para a solução do conflito, o diálogo, a informalidade, a desistitucionalização, a desborucratização e a reparação ou restauração dos prejuízo, são a força motriz de sua existência. Não há, portanto, frente ao crime "vencedores nem vencidos, sem humilhar nem submeter o infrator, sem ameaçá-lo com as iras ou com o peso da lei, sem apelar a força vitoriosa do Direito" ${ }^{46}$.

Por Justiça Restaurativa compreende-se "uma aproximação que privilegia toda a forma de ação, individual ou coletiva, visando corrigir as consequências vivenciadas por ocasião de uma infração, a resolução de um conflito ou a reconciliação as partes ligadas a um conflito" ${ }^{47}$.

Para Gonçalves:

Justiça Restaurativa é uma nova modalidade, baseada num conceito de procedimento por consenso, no qual a vítima e o

\footnotetext{
45 ZEHR, Howard. Trocando as lentes: um novo foco sobre o crime e a justiça restaurativa. Tradução de Tônia VanAcker. São Paulo: Palas Athena, 2008, p. 170.

46 MOLINA, Antonio García-Pablos de; Gomes, Luiz Flávio. Criminologia. 7 ed. São Paulo: Revista dos Tribunais, 2010, p. 417.

47 JACCOUD, Mylène. Princípios, tendências e procedimentos que cercam a Justiça Restaurativa. In: SLAKAMON, C., DE VITTO, R.; PINTO, R. Gomes (Org.). Justiça Restaurativa - Coletânea de artigos. Brasília/DF: Ministério da Justiça e Programa das Nações Unidas para o Desenvolvimento, 2005, p. 169.
} 
PHILIPPI, Patrícia Pasqualini. Justiça restaurativa na contemporaniedade e no porvir: o diálogo democrático, sensível e humano com o direito. Revista Eletrônica Direito e Política, Programa de Pós-Graduação Stricto Sensu em Ciência Jurídica da UNIVALI, Itajaí, v.11, n.3, $3^{\circ}$ quadrimestre de 2016. Disponível em: www.univali.br/direitoepolitica - ISSN 1980-7791

infrator, e, se necessário outras pessoas ou membros da comunidade, direta ou indiretamente, afetados pelo crime, participam de forma coletiva no fomento de soluções para os danos psicológicos, ressentimentos, traumas e perdas causados pelo crime. ${ }^{48}$

Na visão de Rodrigues, esse paradigma "cede o passo a uma justiça negociada, interectiva e horizontal que procura a composição dos interesses utilizando uma racionalidade dialéctica" ${ }^{\prime 49}$.

Essa nova concepção traduzida na Justiça Restaurativa busca aproximar as práticas do sistema punitivo a um modelo democrático de Direito, suavizando os efeitos da dinâmica criminosa e a própria reação social, por meio de diálogo e consenso ${ }^{50}$. "O cidadão sai da passividade para o exercício efetivo de uma democracia com bases humanas" ${ }^{\prime 51}$.

Essa saída, deixa desnudo o crime, que no Sistema Penal tradicional seria uma violação contra o Estado. Na lente da Justiça Restaurativa, o interesse deixa de ser do Estado e passa a ser da vítima. O processo cede lugar ao diálogo, o Pode Estatal cede lugar à vontade da partes, a sentença cede lugar à solução do conflito e a pena, ao consenso restaurador.

Como no toque do bandoleiro, o castigo, cede lugar, ao amor. E certa feita revelou o Papa João Paulo II: "El hombre no puede vivir sin amor. Él permanece

48 GONÇALVES, Antônio Baptista. Justiça Restaurativa: novas soluções para velhos problemas. Revista IOB de Direito Penal e Processual Penal. Porto Alegre: Síntese, v. 9, n. 53, dez/jan. 2008, p. $195 / 196$.

49 RODRIGUES, Anabela Miranda. Novo olhar sobre a questão penitenciária: estudo jurídico do recluso e socialização, jurisdicionalização, consensualismo e prisão. São Paulo: Revista dos Tribunais, 2001, p. 143

50 SANTOS, Hugo Leonardo Rodrigues. Incompatibilidades entre a Justiça Restaurativa e o Instituto da Transação Penal. Revista Síntese Direito Penal e Processual Penal. Porto Alegre: Síntese, v.14, n. 80, jun/jul. 2013, p.44

${ }^{51}$ WARAT, Luis Alberto. 0 ofício do mediador. Florianópolis: Habitus, 2001, p. 218 
PHILIPPI, Patrícia Pasqualini. Justiça restaurativa na contemporaniedade e no porvir: o diálogo democrático, sensível e humano com o direito. Revista Eletrônica Direito e Política, Programa de Pós-Graduação Stricto Sensu em Ciência Jurídica da UNIVALI, Itajaí, v.11, n.3, 30 quadrimestre de 2016. Disponível em: www.univali.br/direitoepolitica - ISSN 1980-7791

para sí mesmo un ser incomprensible, su vida está privada de sentido si no se revela el amor, [...] si no experimenta y [...] si no participa en él vivamente" ${ }^{\prime 52}$.

Tal qual enredo para um romance com final feliz, a Justiça Restaurativa afasta o crime, o castigo, a exclusão e a dor. É como certa feita escreveu Warat:

Opondo Teodoro a Vadinho, encontram-se definidos, para o imaginário de Dona Flor, os lugares do dever e do prazer. Trata-se de um contraste que permite - generalizando a questão - perceber como o desejo pode perder-se quando o lugar do prazer é convertido em um lugar do dever; perdese quando o prazer é realizado como obrigação, como um mecanismo de defesa do desejo frente ao pecado. Sempre que a obrigação repercute no prazer, teremos alguma fora de exercício da repressão. Do mesmo modo teremos alguma forma de neutralização do desejo pela identificação do prazer com o pecado ${ }^{53}$.

É certo que há um abismo entre o romantismo e o realismo, a fantasia e a realidade, o ser e o dever ser, o ideal e o possível. É certo também que a Justiça Restaurativa não é uma panaceia para todos os males ou um milagre de todos os Santos.

Como ensina Baratta:

Nós sabemos que substituir o direito penal por qualquer coisa melhor somente poderá acontecer quando substituirmos a nossa sociedade por uma sociedade melhor, mas não devemos perder de vista que uma política criminal alternativa e a luta ideológica e cultural que a acompanha devem desenvolver-se com vistas à transição para uma sociedade que não tenha necessidade do direito penal burguês, e que devem realizar, no entanto, na fase de de transição, todas as conquistas possíveis para a reapropriação, por parte da sociedade, de um poder alienado, para o desenvolvimento de formas alternativas de

52 O homem não pode viver sem amor. Ele resta para si mesmo um ser incompreensível, sua vida fica privada de sentido se não haja amor, se não experimenta, se dele não participa vivamente. Tradução da própria autora. In: PABLO II, Juan. Encíclica redentor hominis. 4 ed. Madrid: Palabra, 1999, p. 29-30

53 WARAT, Luís Alberto. A ciência jurídica e seus dois maridos. Santa Cruz do Sul: Faculdades Integradas de Santa Cruz do Sul, 1985, p. 23 
PHILIPPI, Patrícia Pasqualini. Justiça restaurativa na contemporaniedade e no porvir: o diálogo democrático, sensível e humano com o direito. Revista Eletrônica Direito e Política, Programa de Pós-Graduação Stricto Sensu em Ciência Jurídica da UNIVALI, Itajaí, v.11, n.3, 30 quadrimestre de 2016. Disponível em: www.univali.br/direitoepolitica - ISSN 1980-7791

autogestão da sociedade, também no campo do controle do desvio ${ }^{54}$.

Na verdade, a aposta que se faz é na tentativa de superar a falência do sistema e da justiça penal, que aliás, é um problema de ordem global e, em alguns casos, trasnacional, visto que, como já dito, muitos dos crimes e de seus autores, ignoram territórios, fronteiras, Estados, nações, povos, soberania, cidadania ou democracia.

Certamente que se trata de um novo modelo de solução de conflitos na esfera penal, que tem como fundamento o diálogo, a conciliação, a mediação e a intermediação entre vítima e infrator, sacando o antiquado, formalista e punitivo Estado, para dar voz e espaço à paz, à justiça social, à razoabilidade e à Socieadade.

De toda forma, não obstante a gama de ideias do que venha ser a Justiça Restaurativa, não há como negar que por tratar-se de um paradgima novo e dada a sua natureza intrinsicamente complexa e aberta, seu conceito não foi finalizado e não é possível apontar com exatidão todos os seus pressupostos e características, ou seja, é um fenômeno jurídico que ainda está no plano da construção. Aliás, como o próprio Direito.

\section{CONTEMPORANIEDADE E O PORVIR: OS CONFLITOS SOCIAIS NO ÂMBITO dO SISTEMA PENAL ${ }^{55}$ E A SUPERAÇÃo do MODELO DE JUSTIÇA RETRIBUTIVA ${ }^{56}$}

\footnotetext{
54 BARATTA, Alessandro. Criminologia Crítica e Crítica do Direito Penal: introdução à sociologia do direito penal. Tradução de Juarez Cirino dos Santos. 3 ed. Rio de Janeiro: Revan, 2002, p. 207

${ }^{55}$ A autora usa o termo Sistema Penal para no plano do discurso retórico englobar Direito e Processo Penal.

56 JUSTIÇA RETRIBUTIVA compreende a ideia do crime como ato contra o Estado, sendo o interesse de punir público. Foca-se o infrator, predominando no caso de punição as penas privativas de liberdade. A vítima recebe pouca assistência e não há consenso, diálogo, entendimento entre os envolvidos. A violação da lei é contra o Estado. O titular da ação penal, predominantemente, é o Estado. O Julgador é o Estado. A pena é aplicada pelo Estado. In: ZEHR,
} 
PHILIPPI, Patrícia Pasqualini. Justiça restaurativa na contemporaniedade e no porvir: o diálogo democrático, sensível e humano com o direito. Revista Eletrônica Direito e Política, Programa de Pós-Graduação Stricto Sensu em Ciência Jurídica da UNIVALI, Itajaí, v.11, n.3, 30 quadrimestre de 2016. Disponível em: www.univali.br/direitoepolitica - ISSN 1980-7791

A contemporaniedade e o futuro enfrentam novas e mais crises e por outro lado, pedem novas e mais soluções. As transformações políticas, econômicas, sociais e culturais evoluem rapidamente em tempo e espaço, sem o que Direito consiga emparelhar-se a elas. As respostas jurídicas, especialmente as legislativas, como na família da Civil Law $^{57}$, mostram-se an grande maioria das vezes tardias e na contramão de direção.

A história nos dá conta que a ideia de um Sistema Penal altamente incriminador e punitivo, não resolveu ou inibiu conflitos, pelo contrário, só fez e ainda os faz aumentá-los.

Isso porque, criou-se e ainda "Cria-se a ilusão de que a repressão, com severo aumento das penas e cerceamento de garantias fundamentais na persecução criminal e na execução das condenações, conterár o avanço da criminalidade" 58 .

A mudança de paradigma é urgente. E essa urgência, radicada na globalização, no multiculturalismo, na velocidade da informação e da comunicação, na interligação e desenvolvimento dos meios produtivos, enfim, na mescla que invade e confunde territórios, pessoas, culturas e ideias faz irromper vários e novos conflitos, que no caminho da evolução social, exige uma resposta à altura da sua racionalidade e do seu bem-estar social. Logo, preemente aceitar um novo olhar para a solução dos conflitos, que passe ao largo da restribuição e do castigo, que já se mostrou fadado ao insucesso.

A Sociedade de risco, fruto de toda movimentação da sua hipercomplexidade reflexiva, exige não apenas a reformulação dos elementos e dos conceitos que a integra, mas, sobretudo, do próprio Direito, tratado aqui no âmbito do Sistema Penal.

Howard. Trocando as Lentes: um novo foco sobre o crime e a justiça. São Paulo: Palos Athenas, 2008

57 Conforme anotação da própria autora, compreende a família Civil Law o Direito legislado, baseado em leis. Codificado.

58 ROSA, Alexandre Morais da; SILVEIRA FILHO, Sylvio Lourenço da. Para um Processo Penal Democrático: crítica à metástase do sistema de controle social. Rio de Janeiro: Lumem Juris, 2009, p. 47 
PHILIPPI, Patrícia Pasqualini. Justiça restaurativa na contemporaniedade e no porvir: o diálogo democrático, sensível e humano com o direito. Revista Eletrônica Direito e Política, Programa de Pós-Graduação Stricto Sensu em Ciência Jurídica da UNIVALI, Itajaí, v.11, n.3, $3^{\circ}$ quadrimestre de 2016. Disponível em: www.univali.br/direitoepolitica - ISSN 1980-7791

Nesse diapasão, a Justiça Restaurativa e suas redes, surgem como um sistema de regulação social para num primeiro plano acompanhar as recentes transformações do direito em geral e também para conter a expansão do direito penal e no seu viés repressivo ${ }^{59}$.

Segundo Azevedo:

A ideia de uma justiça restaurativa aplica-se a práticas de resolução de conflitos baeadas em valores que enfatizam a importância de encontrar soluções para um mais ativo envolvimento das partes no processo, a fim de decidirem melhor a forma de abordar as consequências do delito, bem como as suas repercussões futuras ${ }^{60}$.

Note-se que a diferença fundamental entre o modelo reparador de Justiça Restaurativa e o modelo retributista do Sistema Penal tradicional, reside no fato de que o que se busca no primeiro é solucionar os conflitos, ampliar seu número de soluções e assim melhorar a coexistência social; já no segundo, busca-se apenas decidir os conflitos, aumentando o alcance de atos unilaterais de poder, que se desdobra numa menor solução desses conflitos e na deterioração da coexistência social ${ }^{61}$.

Melhor dizendo, a pretensão da Justiça Restaurativa é abater o sentimento punitivo da vida em comunidade, evoluindo para uma harmonia social, que hoje se mostra mais ameaçada do que preservada pela irracionalidade propagada pela necessidade do castigo ${ }^{62}$.

${ }^{59}$ SICA, Leonardo. Justiça Restaurativa: Críticas e Contra Críticas. Revista IOB de Direito Penal e Processual Penal. Porto Alegre: Síntese, v.8, n. 47, dez./jan.2008, 158

60 AZEVEDO, Rodrigo Ghiringhelli. O paradigma emergente em seu labirinto: notas para o aperfeiçoamento dos juizados especiais criminais. In: WUNDERLICH, Alexandre; CARVALHO, Salo de (Org.). Novos Diálogos sobre os Juizados Especiais Criminais. Rio de Janeiro: Lumem Juris, 2005, p. 136

${ }^{61}$ ZAFFARONI, Eugenio Raúl et.al. Direito Penal Brasileiro: primeiro volume. Teoria Geral do Direito Penal. Rio de Janeiro: Revan, 2003, p.101

62 SICA, Leonardo. Justiça Restaurativa: Críticas e Contra Críticas. Revista IOB de Direito Penal e Processual Penal. Porto Alegre: Síntese, v.8, n. 47, dez./jan.2008, 161 
PHILIPPI, Patrícia Pasqualini. Justiça restaurativa na contemporaniedade e no porvir: o diálogo democrático, sensível e humano com o direito. Revista Eletrônica Direito e Política, Programa de Pós-Graduação Stricto Sensu em Ciência Jurídica da UNIVALI, Itajaí, v.11, n.3, 30 quadrimestre de 2016. Disponível em: www.univali.br/direitoepolitica - ISSN 1980-7791

É preciso, portanto, que articuladamente, se reflita e se admita: 1) primeiro, sobre as transformações da Sociedade Contemporânea e no porvir; 2) segundo, no fato dessa Sociedade se apresentar de risco e hipercomplexa, o que faz aumentar a incidência de conflitos sociais; 3) terceiro, diante da superação do modelo repreensor e retributivo do Sistema Penal, alinhar-se à necessidade de implementação de um modelo restaurador do conflitos e de recomposição das perdas sofridas pela vítima, dialogado, sensível, humano e democrático.

Como alternativa desse pensar, tem-se o modelo de Justiça Restaurativa, que instalada à margem da ação punitiva e retributiva do Estado, realoca a ideia de crime para dentro da Democracia e de proteção aos interesses da vítima por meio do diálogo e da reparação do dano, desburocratizando, desistitucionalizando e desmestificando a força do Direito e do Sistema Penal.

Surge a mesma, desse modo, como uma tentativa de superar a falência do Sistema Penal. Neste sentido explica Santos:

[...] a justiça penal falhou naqueles que deveriam ser os seus objetivos primeiros: não logra ressocializar o agente reintegrando-o enquanto cidadão preparado para respeitar as normas; não garante a satisfação das necessidades concretas da vítima, correspondendo mal às suas expectativas; correspondendo mal às suas expectativas de superação dos danos originados pelo crime; não fomenta a participação comunitária na solução dos problemas comuns nem tem conseguido garantir a pacificação das sociedades alarmadas pela violência e pela criminalidade ${ }^{63}$.

Obviamente que o paradigma da Justiça Restaurativa "não representa uma panaceia, um remédio para todos os males do modelo retributivo, mas introduz nova e boas ideais" ${ }^{\prime 64}$.

Aliás, como já alertou Berestian não há dúvidas de que mediante as estratégias

63 SANTOS, Cláudia. A mediação penal: uma solução divertida? In: FRANCO, Alberto Silva et al. (Org.). Justiça penal portuguesa e brasileira: tendências e reforma. São Paulo: IBCCrim, 2008, p. 36-37.

64 SCURE NETO, Pedro. Manual de sociologia geral e jurídica. 3. E. São Paulo: Saraiva, 1999, p.102. 
PHILIPPI, Patrícia Pasqualini. Justiça restaurativa na contemporaniedade e no porvir: o diálogo democrático, sensível e humano com o direito. Revista Eletrônica Direito e Política, Programa de Pós-Graduação Stricto Sensu em Ciência Jurídica da UNIVALI, Itajaí, v.11, n.3, $3^{\circ}$ quadrimestre de 2016. Disponível em: www.univali.br/direitoepolitica - ISSN 1980-7791

do delinquente e que se compõe em vítima, Mediação e reconciliação, se consiga com certa frequência, maiores satisfações imediatas do que por meio do Sistema Penal tradicional, mas esta constatação só não basta. A prática sem limites da Mediação pode abrir caminho ao funesto sistema punitivo, como o germânico medieval, deixando nas mãos da vítima e seus familiares e sem qualquer racionalidade, a sanção dos delinquentes ${ }^{65}$.

Não se pode mais conceber que pelo vácuo deixado pela ausência do Estado na realização de políticas públicas no sentido de fomentar a melhoria da vida da população, use-se do receituário do movimento Lei e da Ordem, com implementação de uma penalização ainda mais agressiva ${ }^{66}$. Ou ainda pior, incrementando-se a ideia de um direito penal do inimigo ${ }^{67}$.

De toda a sorte, este tipo de cuidado, não afasta a concepção originária de que este novo modelo pode servir como uma forma eficiente e menos conflituosa e até mesmo danosa, de resolução de conflitos penais.

Explica Pinto, que a Justiça Restaurativa não deve ser entendida sob as velhas molduras criminológicas e do direito penal. Ela lança um novo olhar, agregando a interdisciplinaridade de outras ciências, em especial, da Psicologia. E ainda, o foco, nesse contexto de justiça, é alterado e os sujeitos do conflito deixar de ser

${ }^{65}$ BERESTIAN, Antônio. Nova Criminologia: à luz do direito penal e da vitimologia. Tradução de Cândido Furtado Maia Neto. Brasilia: UNB/São Paulo: Imprensa Oficial do Estado, 2000, p. 91. Esta ideia foi também utilizada em outro artigo produzida pela autora sob o título: O Caráter Transnacional das Proposições de Justiça Restaurativa, em abril de 2016. Artigo submetido à publicação.

${ }^{66}$ ROSA, Alexandre Morais da; SILVEIRA FILHO, Sylvio Lourenço da. Para um Processo Penal Democrático: crítica à metástase do sistema de controle social. Rio de Janeiro: Lumem Juris, 2009, p. 44

67 Teoria desenvolvida por Günther Jakobs, em que separa o cidadão, sujeito digno de direitos, do inimigo, sujeito que viola as leis e que, portanto, perde determinados direitos. JAKOBS, Günther. Direito Penal do cidadão e direito penal do inimigo. In: JAKOBS, Günther; CANCIO MELIÁ, Manuel. Direito Penal do Inimigo: noções e críticas. Tradução de André Luís Callegari e Nereu José Giacomolli. Porto Alegre: Livraria do Advogado, 2005 
PHILIPPI, Patrícia Pasqualini. Justiça restaurativa na contemporaniedade e no porvir: o diálogo democrático, sensível e humano com o direito. Revista Eletrônica Direito e Política, Programa de Pós-Graduação Stricto Sensu em Ciência Jurídica da UNIVALI, Itajaí, v.11, n.3, $3^{\circ}$ quadrimestre de 2016. Disponível em: www.univali.br/direitoepolitica - ISSN 1980-7791

objetos de tratamento do sistema jurídico para se tornar protagonistas do próprio processo ${ }^{68}$.

O conflito pode possuir um potencial construtivo, quanto mais quando resolvido pelo diálogo e o consenso. Como disse Warat o conflito pode denotar "uma forma de inclusão do outro na produção do novo: o conflito como outrocidade que permita administrar, com o outro, o diferente e produzir a diferença"69.

É preciso ter cuidado, pois, a cultura do medo - política, propositada e propagandeada, acaba por internalizar no inconsciente social a necessidade de uma política criminal do terror, com um aparato voltado a solução de conflitos mediante o aumento dos crimes e das penas, quando, por certo, a Sociedade deveria caminhar à margem dessa perniciosa, truculenta e retrógada ideia, que mais se assemelha ao velho ditado popular: "dar um tiro no próprio pé".

Colet afirma que:

Em oposição aos ideias de confronto e aniquilação do outro, do qual um vence em face da derrota do outro, gerando assim, sentimento de vingança e ódio, desejos por sangue e revanche, a Justiça Restaurativa cria condições para que a vítima e ofensor possam se encontrar e produzir um cenário baseado em diálogo, reflexão no erro e na humanidade do ato de errar e perdoar. O modelo reconhece que a prática do crime afeta a relação entre vítima e autor do fato, como a relação desses com suas comunidades, razão pela qual oportuniza e encoraja as pessoas envolvidas no conflito a serem sujeitos centrais do processo. A partir da exposição dos sentimentos e necessidades, da capacidade de assumir a responsabilidade e reparação do dano, o modelo promove a satisfação de cada parte e a cura, desencadeando a produção de um resultado socialmente terapêutico ${ }^{70}$.

68 PINTO, Renato Sócrates Gomes. Justiça Restaurativa: um novo caminho? Revista IOB de Direito Penal e Processual Penal. Porto Alegre: Síntese, v.8, n. 47, dez./jan.2008, 193

69 WARAT, Luis Alberto. O ofício do mediador. Florianópolis: Habitus, 2001, p. 82. Esta ideia foi também utilizada em outro artigo produzida pela autora sob o título: O Caráter Transnacional das Proposições de Justiça Restaurativa, em abril de 2016. Artigo submetido à publicação

70 COLET, Paula Charlise. A promoção dos direitos mínimos do cidadão realizada pelas práticas restauradoras: a quebra da cultura excludente e seletiva do sistema penal. In: CALLEGARI, André Luís (Org.); COLET, Charlise Paula; WERMUTH, Maiquel Ângelo Dezordi; ANDRADE, Roberta 
PHILIPPI, Patrícia Pasqualini. Justiça restaurativa na contemporaniedade e no porvir: o diálogo democrático, sensível e humano com o direito. Revista Eletrônica Direito e Política, Programa de Pós-Graduação Stricto Sensu em Ciência Jurídica da UNIVALI, Itajaí, v.11, n.3, $3^{\circ}$ quadrimestre de 2016. Disponível em: www.univali.br/direitoepolitica - ISSN 1980-7791

Ora, na mesma forma que as transformações sociais são intensas, o Direito também deve transcender seus antigos limites e conceitos. Seu devenir, deve pautar-se na ideia do humano, do democrático e do consenso.

A fala, a tolerância o consenso devem substituir 0 atual sistema repressivo/punitivo. "O diálogo democrático precisa ser vivenciado nas relações Pessoa versus pessoa, Sociedade versus Estado, e entre os distintos Estados no contexto global do mundo"71.

É claro que este é ainda um modelo em construção e experimento. Logo, nele permeiam apostas e críticas. As críticas repousam desde o fomento da vitimologia, podendo a vítima, ao tomar o lugar do Estado ser mais beligerante que o próprio ao especulado aumento de casos, e portanto, à reboque, com a sua banalização, o que resultará na quase que obrigatória intervenção do Estado para decidir ou mandar cumprir aquilo que por vezes já foi decidido na esfera particular.

Também como afirma Prado, por afetar a justiça consensual as garantias básicas que o processo judicial oferece ${ }^{72}$, ou ainda, como prefere Lopes Jr. por representar uma forma utilitarista, eficiente mas antigaranstista ${ }^{73}$, a Justiça Restaurativa estaria por violar direitos e garantias Constitucionais, violando assim as bases do Estado Democrático de Direito.

Lofrano. Direito Penal e globalização: sociedade de risco, imigração irregular e justiça restaurativa. Porto Alegre: Livraria do Advogado Editora, 2011, p. 92-93

71 DIAS, Maria da Graça dos Santos Dias; JUNIOR, Airto Chave. Mediação: uma terceria de caráter político-pedagógico. In: SPENGLER, Fabiana Marion. BRANDÃO, Paulo de Tarso; Os (des)caminhos da Jurisdição. Florianópolis: Conceito Editorial, 2009, p. 224

72 PRADO, Geraldo. Justiça Penal Consensual. In: Diálogos Sobre a Justiça Dialogal. SALO, de Carvalho; WUNDERLICH, Alexandre. Rio de Janeiro: Lumem Juris, 2002, p. 81-99

73 LOPES JR., Aury. Justiça Negociada: utilitarismo processual e eficiência antigarantista. In: Diálogos Sobre a Justiça Dialogal. SALO, de Carvalho; WUNDERLICH, Alexandre. Rio de Janeiro: Lumem Juris, 2002, p. 113 
PHILIPPI, Patrícia Pasqualini. Justiça restaurativa na contemporaniedade e no porvir: o diálogo democrático, sensível e humano com o direito. Revista Eletrônica Direito e Política, Programa de Pós-Graduação Stricto Sensu em Ciência Jurídica da UNIVALI, Itajaí, v.11, n.3, 30 quadrimestre de 2016. Disponível em: www.univali.br/direitoepolitica - ISSN 1980-7791

De toda maneira, interessa estudar, debater e investigar a proposta e as alternativas da Justiça Restaurativa, que, senão a forma ideal, ao menos é uma forte representante do modelo penal mínimo e que fortalece os direitos de dignidade humana, liberdade e cidadania.

É preciso compreender que o Sistema Penal não é um meio único e eficiente para exorcizar todas as crises e dificuldadees encontradas na Sociedade Contemporânea, muito menos, do que se espera dela. Aliás, pelo contrário, é fora do Sistema Penal, ou na sua mínima incidência, respeitando as diferentes concepções humanas, que se podereá alcancar, ou mais perto chegar, de mundo bem melhor.

Essa ruptura de paradigma, que supera o Sistema Penal e que abre portas a uma nova forma de compreender o Direito, obriga não só ao redesenho de um ordenamento jurídico, mas também uma política, uma Sociedade e uma cultura que priorize o diálogo, a reconstrução social, a conviviabilidade e a democracia. Esse é verdadeiramente um sinal de esperança na luta contra o jugo, a pervesidade e a insensatez que perspassa toda a história da humanidade. Esse parece ser o caminho aberto, mas não todo desbravado pela a Justiça Restaurativa, cuja reflexidade se mostra como uma alternativa mais humana e civilizada de se pensar, viver, e sobretudo, de convivência.

\section{CONSIDERAÇÕES FINAIS}

O presente artigo buscou explorar uma novo olhar para o Direito, aliando a ideia de implementação da Justiça Restaurativa como um meio, um novo modelo de solução de conflitos que tem sua genêse no diálogo das partes envolvidas, no humano, no sensível e no democrático.

A recomposição e a restauração do dano inflingido à vítima, pelo viés da Justiça Restaurativa, procura afastar do Estado a possibilidade de impor a força punitiva, repressora, e estigmatizante que alimenta e é a base de sustentação do Sistema Penal, fazendo com que os indivíduos possam, ou ao menos Ihes seja facultado, 
PHILIPPI, Patrícia Pasqualini. Justiça restaurativa na contemporaniedade e no porvir: o diálogo democrático, sensível e humano com o direito. Revista Eletrônica Direito e Política, Programa de Pós-Graduação Stricto Sensu em Ciência Jurídica da UNIVALI, Itajaí, v.11, n.3, 30 quadrimestre de 2016. Disponível em: www.univali.br/direitoepolitica - ISSN 1980-7791

resolver pela via do entendimento, do consenso e da tolerância na coexistência, resolver os conflitos que Ihes envolve.

A Justiça Restaurativa é uma tentativa de se implementar um Direito mais humano, civilizado e que cabe perfeitamente num Estado Democrático de Direito. A contemporaniedade e o porvir, apresentam um nova arquitetura política, social, econômica e cultural. Logo, a ordem jurídica também precisa ser redesenhada, reformulada, reestruturada e porque não, reinventada.

Certamente que a Justiça Restaurativa não é uma obra perfeita e acabada. Sobre ela existem e pairam críticas e contracríticas. O fato é que, ela representa uma tentativa, algo que pode e deve ser experimentado em todas as suas possibilidades.

No mais, a velha fórmula punitiva e repressora imposta pelo Estado, arraigadas no Sistema Penal, já não serviam ao passado, quanto mais ao presente e ao futuro, cuja dimensão e a complexidade das relações humanas é outra. Na Sociedade de risco, reflexo da modernidade, da globalização, da tecnologia, do multiculturalismo, da movimentação humana e de coisas, a ostensividade e a hostilidade penal só servirão de combustível para o aumento da criminalidade e, consequentemente, da própria força controlado, punitiva e castradora do Estado.

A Justiça Restaurativa é, nesse pensar e sentir, uma alternativa, uma opção, um caminho a ser trilhado para superar antigos dogmas penais. Sua proposta democrática e humana de solução de conflitos surge como um fio de esperança de que o sensível vença não só um Sistema Penal decadente e ultrapassado, mas a frieza, a frívolidade e a cólera que hoje, infelizmente, envolve o indivíduo na sua relação com o outro.

Por fim é evidente que o o assunto não se mostra esgotado, pelo contrário, merece debate, crítica, entendimento e aprofundamento. A Justiça Restaurativa, como toda proposta, pende de estudo e investigação. 
PHILIPPI, Patrícia Pasqualini. Justiça restaurativa na contemporaniedade e no porvir: o diálogo democrático, sensível e humano com o direito. Revista Eletrônica Direito e Política, Programa de Pós-Graduação Stricto Sensu em Ciência Jurídica da UNIVALI, Itajaí, v.11, n.3, 30 quadrimestre de 2016. Disponível em: www.univali.br/direitoepolitica - ISSN 1980-7791

\section{REFERÊNCIAS DAS FONTES CITADAS}

ABREU, Pedro Manuel. Processo e Democracia: o processo jurisdicional como um locus da democracia participativa e da cidadania inclusiva no estado democrático de direito. v.3. São Paulo: Conceito Editorial, 2011.

ALEXY, Robert. Teoria dos Direitos Fundamentais. Tradução de Virgílio Afonso da Silva. São Paulo: Malheiros Editores, 2008, p. 140.

AZEVEDO, Rodrigo Ghiringhelli. O paradigma emergente em seu labirinto: notas para o aperfeiçoamento dos juizados especiais criminais. In: WUNDERLICH, Alexandre; CARVALHO, Salo de (Org.). Novos Diálogos sobre os Juizados Especiais Criminais. Rio de Janeiro: Lumem Juris, 2005.

BECK, Ulrich. Sociedade de Risco: rumo a uma outra modernidade. 2 ed. Tradução de Sebastião Nascimento. São Paulo: Editora 34, 2011.

BERESTIAN, Antônio. Nova Criminologia: à luz do direito penal e da vitimologia. Tradução de Cândido Furtado Maia Neto. Brasilia: UNB/São Paulo: Imprensa Oficial do Estado, 2000.

BRANDÃO, Paulo de Tarso. As Ações Constitucionais: novos direitos e acesso à justiça. Florianópolis: Habitus, 2001.

BRAITHWAITE, John. Crime, shame and reintegration. Cambridge: Cambridge University Press, 1989.

CADERMATORI. Daniela Mesquita Leutchuk de. Limites e Possibilidades de uma Cidadania Transnacional: uma apreensão histórico-cultural. In: CRUZ, Paulo Márcio; STELZER, Joana (Orgs.) Direito e Transnacionalidade. Curitiba: Juruá, 2011.

CALLEGARI, André Luís. Sociedade de Risco e Direito Penal. In: CALLEGARI, André Luís (Org.); COLET, Charlise Paula; WERMUTH, Maiquel Ângelo Dezordi; ANDRADE, Roberta Lofrano. Direito Penal e globalização: sociedade de risco, imigração irregular e justiça restaurativa. Porto Alegre: Livraria do Advogado Editora, 2011.

CANOTILHO, José Joaquim Gomes. Estado de direito. Coimbra: Gradiva, 1999.

COELHO, Luiz Fernando. Saudade do Futuro: transmodernidade, direito, utopia. Florianópolis: Fundação Boiteux, 2001.

COLET, Paula Charlise. A promoção dos direitos mínimos do cidadão realizada pelas práticas restauradoras: a quebra da cultura excludente e seletiva do sistema penal. In: CALLEGARI, André Luís (Org.); COLET, Charlise Paula; WERMUTH, Maiquel Ângelo Dezordi; ANDRADE, Roberta Lofrano. Direito Penal e globalização: sociedade de risco, imigração irregular e justiça restaurativa. Porto Alegre: Livraria do Advogado Editora, 2011. 
PHILIPPI, Patrícia Pasqualini. Justiça restaurativa na contemporaniedade e no porvir: o diálogo democrático, sensível e humano com o direito. Revista Eletrônica Direito e Política, Programa de Pós-Graduação Stricto Sensu em Ciência Jurídica da UNIVALI, Itajaí, v.11, n.3, $3^{\circ}$ quadrimestre de 2016. Disponível em: www.univali.br/direitoepolitica - ISSN 1980-7791

CONSELHO NACIONAL DE JUSTIÇA. Disponível em: http://www.cnj.jus.br/noticias/cnj/81051-cnj-servico-conceitos-basicos-dajustica-restaurativa. Acesso em 03/04/2016.

CONVENÇÃO DAS NAÇÕES UNIDAS CONTRA O CRIME ORGANIZADO. Nova York, 15/11/2000. Disponível em: http://www.gddc.pt/cooperacao/materiapenal/textos- Penal/onu/ConvCrimOrganiz.pdf. Acesso em 03/04/2016.

CRUZ, Paulo Márcio; STELZER, Joana (Orgs.). Direito e Transnacionalidade. Curitiba: Juruá, 2011.

CRUZ, Paulo Márcio; BODNAR, Zenildo. O Novo Paradigma de Direito na PósModernidade. Porto Alegre. RECHTD/UNISINOS. RECHTD. Revista de Estudos Constitucinais, Hermenêutica e Teoria do Dieito, v. 3, p. 75-83, 2011.

CRUZ, Paulo Márcio. Política, Poder, Ideologia \& Estado Contemporâneo. Curitiba: Juruá, 2002.

CRUZ, Paulo Márcio. Da soberania à transnacionalidade: democracia, direito e estado no século XXI. Itajaí: Universidade do Vale do Itajaí, 2011.

CRUZ, Paulo Marcio; SCHMITZ, Sérgio Antônio. Sobre o Princípio Republicano. NEJ.- Vol. 13 - 1- p. 43-54/jan-jun 2008.

CRUZ, Paulo Márcio. Fundamentos do Direito Constitucional. 2 ed. Curitiba: Juruá, 1998.

DIAS, Maria da Graça dos Santos Dias; JUNIOR, Airto Chave. Mediação: uma terceria de caráter político-pedagógico. In: SPENGLER, Fabiana Marion; BRANDÃO, Paulo de Tarso; Os (des)caminhos da Jurisdição. Florianópolis: Conceito Editorial, 2009.

FERNANDES, Paulo Silva. Globalização, "Sociedade de Risco" e o Futuro do Direito Penal. Coimbra: Livraria Almedina, 2001.

GONÇALVES, Antônio Baptista. Justiça Restaurativa: novas soluções para velhos problemas. Revista IOB de Direito Penal e Processual Penal. Porto Alegre: Síntese, v. 9, n. 53, dez/jan. 2008.

HABERMAS, Jürgen. Direito Democracia - entre facticidade e validade. Trad. Flávio Beno Siebeneichler. Rio de Janeiro: Tempo Brasileiro, v. I e II, 2003.

HESSE, Konrad. Elementos do Direito Constitucional da República Federal da Alemanha. Tradução Luís Afonso Heck. Porto Alegre: Sérgio Antônio Fabris, 1995.

JAKOBS, Güinter. Autor da teoria do direito penal do inimigo, em que separa a figura do homem cidadão da figura do homem inimigo e que escreveu com CANCIO, Manuel Meliá a obra Direito Penal do Inimigo: Noções e Críticas. Porto Alegre. 3 ed. 2008. 
PHILIPPI, Patrícia Pasqualini. Justiça restaurativa na contemporaniedade e no porvir: o diálogo democrático, sensível e humano com o direito. Revista Eletrônica Direito e Política, Programa de Pós-Graduação Stricto Sensu em Ciência Jurídica da UNIVALI, Itajaí, v.11, n.3, $3^{\circ}$ quadrimestre de 2016. Disponível em: www.univali.br/direitoepolitica - ISSN 1980-7791

JACCOUD, Mylène. Princípios, tendências e procedimentos que cercam a Justiça Restaurativa. In: SLAKAMON, C., DE VITTO, R.; PINTO, R. Gomes (Org.). Justiça Restaurativa - Coletânea de artigos. Brasília/DF: Ministério da Justiça e Programa das Nações Unidas para o Desenvolvimento, 2005.

LOPES JR., Aury. Justiça Negociada: utilitarismo processual e eficiência antigarantista. In: Diálogos Sobre a Justiça Dialogal. SALO, de Carvalho; WUNDERLICH, Alexandre. Rio de Janeiro: Lumem Juris, 2002.

MARTINEZ, Gregório Perces-Barba. Derecho y derecho fundamentales. Madri: Centro de Estudios Constitucionales, 1993.

MIRANDA, Jorge. Manual de Direito Constitucional. v.4. Coimbra: Coimbra, 1988.

MOLINA, Antonio García-Pablos de; Gomes, Luiz Flávio. Criminologia. 7 ed. São Paulo: Revista dos Tribunais, 2010.

PASOLD, Cesar Luiz. Metodologia da Pesquisa Jurídica: teoria e prática. 12. ed. rev. São Paulo: Conceito Editorial, 2011.

PASOLD, Cesar; SANTO, Davi do Espírito. Reflexões sobre a Teria da Constituição e do Estado. Florianópolis: Insular, 2013.

PINTO, Renato Sócrates Gomes. Justiça Restaurativa: um novo caminho? Revista IOB de Direito Penal e Processual Penal. Porto Alegre: Síntese, v.8, n. 47, dez./jan. 2008.

PRADO, Geraldo. Justiça Penal Consensual. In: Diálogos Sobre a Justiça Dialogal. SALO, de Carvalho; WUNDERLICH, Alexandre. Rio de Janeiro: Lumem Juris, 2002.

RODRIGUES, Anabela Miranda. Novo olhar sobre a questão penitenciária: estudo jurídico do recluso e socialização, jurisdicionalização, consensualismo e prisão. São Paulo: Revista dos Tribunais, 2001.

ROSA, Alexandre Morais da; SILVEIRA FILHO, Sylvio Lourenço da. Para um Processo Penal Democrático: crítica à metástase do sistema de controle social. Rio de Janeiro: Lumem Juris, 2009.

SÁNCHEZ, Jesús-María Silva. Aproximación al Derecho Penal Contemporâneo. Barcelona: José Maria Bosch Editor, 1992.

SANTOS, Cláudia. A mediação penal: uma solução divertida? In: FRANCO, Alberto Silva et al. (Org.). Justiça penal portuguesa e brasileira: tendências e reforma. São Paulo: IBCCrim, 2008.

SANTOS, Hugo Leonardo Rodrigues. Incompatibilidades entre a Justiça Restaurativa e o Instituto da Transação Penal. Revista Síntese Direito Penal e Processual Penal. Porto Alegre: Síntese, v.14, n. 80, jun/jul. 2013. 
PHILIPPI, Patrícia Pasqualini. Justiça restaurativa na contemporaniedade e no porvir: o diálogo democrático, sensível e humano com o direito. Revista Eletrônica Direito e Política, Programa de Pós-Graduação Stricto Sensu em Ciência Jurídica da UNIVALI, Itajaí, v.11, n.3, 30 quadrimestre de 2016. Disponível em: www.univali.br/direitoepolitica - ISSN 1980-7791

SCURE NETO, Pedro. Manual de sociologia geral e jurídica. 3. E. São Paulo: Saraiva, 1999.

SICA, Leonardo. Justiça Restaurativa: Críticas e Contra Críticas. Revista IOB de Direito Penal e Processual Penal. Porto Alegre: Síntese, v.8, n. 47, dez./jan.2008.

STRECK, Maria Luiza Schafer. Direito penal e Constituição: a face oculta da proteção dos direitos fundamentais. Porto Alegre: Livraria do Advogado Editora, 2009.

SILVA, Moacyr Motta da. Direito e Sensibiliade. In: DIAS, Maria da Graça dos Santos; MELO, Osvaldo Ferreira de; Silva, Moacyr Motta da. Política Jurídica e Pós- Modernidade. Florianópolis: Conceito Editorial, 2009.

SILVA, Ildete Regina Vale da; BRANDÃO, Paulo de Tarso. Constituição e Fraternidade: o valor normativo do preâmbulo da constituição. Curitiba: Juruá, 2015.

STELZER, Joana. O Fenômeno da Transnacionalização da Dimensão Jurídica. In: CRUZ, Paulo Márcio; STELZER, Joana (Orgs.) Direito e transnacionalidade. Curitiba: Juruá, 2011.

WARAT, Luis Alberto. O ofício do mediador. Florianópolis: Habitus, 2001.

WARAT, Luís Alberto. A ciência jurídica e seus dois maridos. Santa Cruz do Sul: Faculdades Integradas de Santa Cruz do Sul, 1985.

WERMUTH, Maiquel Ângelo Dezordi. Mixofobia: a construção dos imigrantes ilegais como "sujeitos de risco" e o tratamento jurídico-penal da imigração irregular na União Europeia como retrocesso rumo a um modelo de Direito Penal de autor. In: CALLEGARI, André Luís (Org.); COLET, Charlise Paula; WERMUTH, Maiquel Ângelo Dezordi; ANDRADE, Roberta Lofrano. Direito Penal e globalização: sociedade de risco, imigração irregular e justiça restaurativa. Porto Alegre: Livraria do Advogado Editora, 2011.

ZAFFARONI, Eugenio Raúl et.al. Direito Penal Brasileiro: primeiro volume. Teoria Geral do Direito Penal. Rio de Janeiro: Revan, 2003.

ZEHR, Howard. Trocando as lentes: um novo foco sobre o crime e a justiça restaurativa. Tradução de Tônia VanAcker. São Paulo: Palas Athena, 2008.

Submetido em: setembro/2016

Aprovado em: novembro/2016 